\title{
Response of Wumeng Semi-Fine Wool Sheep to Copper-Contaminated Environment
}

\author{
Ting Wu ${ }^{1}$, Xiaoyun Shen ${ }^{1,2,3 *}$ \\ ${ }^{1}$ School of Life Science and Engineering, Southwest University of Science and Technology, Mianyang, China \\ ${ }^{2}$ State Engineering Technology Institute for Karst Desertification Control, Guizhou Normal University, Guiyang, China \\ ${ }^{3}$ World Bank Poverty Alleviation Project Office in Guizhou, Southwest China, Guiyang, China
}

Received: 2 June 2019

Accepted: 21 August 2019

\begin{abstract}
We evaluated the response of Wumeng semi-fine wool sheep to a copper-contaminated environment and found an action plan to solve copper pollution through a grazing experiment and ammonium molybdate supplementary experiment carried out in Weining County of Guizhou Province in China. The content of heavy metal element in soil, herbage, and animal tissues was measured by atomic absorption spectrometry, and the blood physiological and biochemical indicators were determined by animalspecific automatic blood analyzer and automatic biochemical analyzer respectively. The results showed that the copper content in soil and herbage of contaminated pasture was significantly higher than that in control pasture, and the copper content in blood and liver in affected sheep was significantly higher than that in the control group. Hemoglobin (Hb), red blood cell count (RBC), hematocrit (PCV), mean corpuscular volume (MCV) contents and superoxide dismutase (SOD), catalase (CAT), and glutathione peroxidase (GSH-Px) activities in affected sheep were significantly lower than those in control, while the activities of ceruloplasmin (CP), glutamic oxaloacetic transaminase (GOT), creatine phosphokinase (CPK) and malondialdehyde (MDA) were significantly higher. There was no significant difference in the level of mean corpuscular hemoglobin $(\mathrm{MCH})$, mean corpuscular hemoglobin concentration (MCHC) and white blood cell count (WBC) between the affected and control sheep. After supplementation of ammonium molybdate, copper content in blood and liver decreased gradually, and the abnormal blood indexes recovered. At the end of the ammonium molybdate supplementation experiment, Wumeng semi-fine wool sheep in the drug-control group (CK group) showed hemoglobinuria, jaundice, anemia and other symptoms. Conclusion: a copper-contaminated environment seriously affected mineral metabolism and blood physiological and biochemical indicators of Wumeng semi-fine wool sheep, and we can utilize the antagonism of molybdenum and copper in the diet to achieve the goal of harmless utilization of a copper-polluted meadow.
\end{abstract}

Keywords: Wumeng semi-fine wool sheep, heavy metal, copper-contaminated environment, blood index

*e-mail: shenxy@swust.edu.cn 


\section{Introduction}

Wumeng semi-fine wool sheep, formerly known as Guizhou semi-fine wool sheep, is a variety that was examined and approved in the early 1990s [1]. They were bred by introducing Weining sheep (Tibetan valley type coarse wool sheep) with Corriedale, Merino sheep and Xinjiang fine wool sheep. Hence, it has some excellent characteristics, such as good adaptability, greater disease resistance, great ability to endure roughage, obedient disposition, and easy management, and the demand for forage quality is not high [2]. Compared with Weining sheep, production performance was significantly improved. The average body weights of adult rams and ewes are $61.62 \pm 5.38 \mathrm{~kg}$ and $52.76 \pm 5.93 \mathrm{~kg}$ respectively, the average wool yields are $5.86 \pm 1.27 \mathrm{~kg}$, and $4.72 \pm 1.13 \mathrm{~kg}$ respectively, the main fineness of wool is $25.00-29.00 \mu \mathrm{m}$, wool yield is $57.72 \%$, and the lambing rate is $119.59 \%$ [1, 3]. At present, Wumeng semi-fine wool sheep have been extended to Weining, Hezhang and Shuicheng counties in Guizhou Province, accounting for $62 \%$ of sheep in stock. Wumeng semi-fine wool sheep play an important role in the grassland stockbreeding economy of Guizhou and is the main source of local productive life material in the Wumeng mountainous area [4].

Heavy metal pollution refers to the environmental pollution caused by heavy metals or their compounds [5]. Heavy metal pollution was the result of artificial causes such as mining, exhaust and wastewater emissions, sewage irrigation, etc. [6]. Heavy metals in soil are difficult to degrade, and the high accumulation of these metals induces adverse effects on plant growth, which may cause the problem of toxicities in animals depending on plants and forage material $[7,8]$. Wumeng mountainous area is the natural habitat of Wumeng semi-fine wool sheep, where forage resources and unique natural conditions for developing grassland animal husbandry abound. However, in recent years, due to the exploitation and utilization of mineral resources, the area has become a heavy metal pollution area in China, with copper one of the main culprits, which seriously affects the development of local animal husbandry [5].

For the purpose of studying the effects of a coppercontaminated environment on Wumeng semi-fine wool sheep, the mineral elements content in soil, herbage, blood and liver, and blood indexes of Wumeng semifine wool sheep were detected in this experiment. By adding different levels of ammonium molybdate into the diet to found the suitable treatment methods, which could provide reference for the prevention and treatment of chronic copper poisoning and loss reduction of the sheep-breeding industry.

\section{Materials and Methods}

\author{
Study Area
}

The study area is located in Weining County $\left(26^{\circ} 30^{\prime}-27^{\circ} 25^{\prime} \mathrm{N}, 103^{\circ} 36^{\prime}-104^{\circ} 45^{\prime} \mathrm{E}\right)$, which belongs to the subtropical and warm temperate monsoon climate, with an average altitude of 1550-2200 $\mathrm{m}$, annual average temperature of $11.5-11.8^{\circ} \mathrm{C}$, a frost-free period of 180-257 d, annual average rainfall of $890-1150 \mathrm{~mm}$, and average sunshine duration of 1400-1800 h.

\section{Experimental Design}

20 Wumeng semi-fine wool sheep were selected from the pasture of Niupeng town (affected group) and Liangshuigou sheep stud farm (control group), respectively. Mineral elements in soil, herbage, blood and liver were determined, and blood physiological and biochemical indexes were measured. Then, 20 sheep from the control pasture were transferred to an affected pasture and randomly divided into 4 groups for isolation grazing. After 30 days, combined with the test results of Guan [9], 3 groups of sheep were supplemented with ammonium molybdate $\left(\left(\mathrm{NH}_{4}\right)_{2} \mathrm{Mo}_{2} \mathrm{O}_{7}\right)$ with 100,200 , $300 \mathrm{mg} / \mathrm{kg}$ respectively for 60 days ( 2 every $10 \mathrm{~d}$ ), and the rest of the group was not added (drug control group, CK). Copper contents in blood and liver in sheep were measured every 20 days during supplementary feeding with ammonium molybdate. And blood physiological and biochemical indexes were measured again at the end of the ammonium molybdate supplementation experiment.

\section{Sample Collection}

\section{Soil and Herbage Sample}

Twenty $200-\mathrm{g}$ soil samples were collected from the surface layer $(0-30 \mathrm{~cm})$ of each pasture, then dried at $60-80^{\circ} \mathrm{C}$ for $48 \mathrm{~h}$, and passed through a $0.154-\mathrm{mm}$ sieve. Herbage samples $(200 \mathrm{~g})$ were also collected from each pasture. To reduce the influence of soil contamination, the herbage samples were harvested $1-2 \mathrm{~cm}$ above ground level, then dried at $60-80^{\circ} \mathrm{C}$ for $48 \mathrm{~h}$ and passed through a $0.071-\mathrm{mm}$ sieve.

\section{Blood Sample}

The jugular vein blood of sheep was collected by aseptic vacuum blood sampling. Each sheep was $20 \mathrm{~mL}$, of which $10 \mathrm{~mL}$ was used to determine the blood mineral content, and another $10 \mathrm{~mL}$ was used to determine physiological and biochemical indexes. According to Yao et al., the angle and length of the rapid biopsy needle passing through the right hepatic region skin was $45^{\circ}$ and $6 \mathrm{~cm}$ respectively to obtain liver samples [10]. 
Determination and Method

\section{Mineral Element Content}

Content of manganese $(\mathrm{Mn})$, zinc $(\mathrm{Zn})$, cobalt $(\mathrm{Co})$, copper $(\mathrm{Cu})$, molybdenum (Mo), and selenium (Se) in the pastures were determined by atomic absorption spectrometry (model no. XDY-2A; PerkinElmer, Inc., Waltham, MA, USA) [11]. The ammonium molybdate spectrophotometric method determined element phosphorus (P) [12].

\section{Blood Physiological and Biochemical Indicators}

Hemoglobin ( $\mathrm{Hb})$, red blood cell count (RBC), hematocrit (PCV), mean corpuscular volume $(\mathrm{MCV})$, mean corpuscular hemoglobin $(\mathrm{MCH})$, mean corpuscular hemoglobin concentration (MCHC), and white blood cell count (WBC) in blood were determined using an animal-specific automatic blood analyzer (SF-3000, Sysmex Corporation, Kobe, Japan).

Blood levels of glutathione peroxidase (GSH-Px), glutamic oxaloacetic transaminase (GOT), catalase (CAT), creatine phosphokinase (CPK), superoxide dismutase (SOD), malondialdehyde (MDA), and ceruloplasmin (CP) were determined using an automatic biochemical analyzer (Olympus AU 640, Olympus Corporation, Tokyo, Japan).

\section{Data Analysis}

All data analyses were conducted using IBM SPSS Statistics for Windows software, version 20.0 (IBM Inc., Armonk, NY, USA), and the results were presented as the "mean \pm standard error". Significant differences between groups were identified using Student's t-test. A probability $(P)$ value of $<0.01$ was considered statistically significant.

\section{Results}

\section{Mineral Element Content}

The pasture was severely affected, with copper contents in soil significantly exceeding that in the control pasture $(P<0.01)$ and the national environmental quality standards of copper pollution in China (35 mg/kg, GB15618-1995). The copper content in herbage of affected pasture was also significantly greater than that in the control pasture $(P<0.01)$ (Table 1). There were no significant differences in the content of other elements in soil and herbage between the two pastures. The ratio of copper and molybdenum was significantly greater in herbage of the affected pasture than that in common animal feed (23.05:1 vs. 6-10:1, respectively) [13]. Copper content in blood and liver in the affected group were significantly higher than those in control group $(P<0.01)$ (Table 2), with no significant difference in other elements $(P>0.05)$. According to Wang et al., when the content of copper in liver exceeds $500 \mathrm{mg}$, it can be regarded as copper poisoning [14]. Therefore, Wumeng semi-fine wool sheep grazing on affected pasture were in a copper poisoning state.

\section{Biophysical and Biochemical Parameters}

Blood levels of $\mathrm{Hb}, \mathrm{RBC}, \mathrm{PCV}$ and $\mathrm{MCV}$ in the affected group were significantly lower than those in control $(P<0.01$, Table 3$)$. There was no significant difference in the levels of $\mathrm{MCH}, \mathrm{MCHC}$ and $\mathrm{WBC}$ between the affected and control sheep $(P>0.05)$. SOD, CAT and GSH-Px activities in blood in the affected group were significantly lower than control $(P<0.01)$ (Table 4), while $\mathrm{Cp}$, GOT, CPK and MDA were significantly greater $(P<0.01)$ (Table 4$)$.

Table 1. Mineral contents of soil and herbage $\mathrm{mg} / \mathrm{kg}(\mathrm{DM})$.

\begin{tabular}{|c|c|c|c|c|}
\hline \multirow{2}{*}{ Element } & \multicolumn{2}{|c|}{ Soil } & \multicolumn{2}{c|}{ Herbage } \\
\cline { 2 - 5 } & Affected pasture & Control pasture & Affected pasture & Control pasture \\
\hline $\mathrm{Mn}$ & $312.67 \pm 27.56$ & $289.29 \pm 25.36$ & $62.79 \pm 11.91$ & $57.93 \pm 5.67$ \\
\hline $\mathrm{Zn}$ & $45.17 \pm 11.67$ & $44.19 \pm 9.53$ & $87.68 \pm 13.61$ & $87.69 \pm 7.83$ \\
\hline $\mathrm{Co}$ & $6.15 \pm 1.27$ & $6.13 \pm 1.35$ & $1.52 \pm 0.63$ & $1.49 \pm 0.67$ \\
\hline $\mathrm{Cu}$ & $71.83 \pm 7.73 \mathrm{a}$ & $11.87 \pm 2.63 \mathrm{~b}$ & $26.97 \pm 3.29$ & $7.27 \pm 2.73$ \\
\hline $\mathrm{P}$ & $447.77 \pm 37.68$ & $438.97 \pm 34.45$ & $457.89 \pm 33.72$ & $453.29 \pm 31.76$ \\
\hline $\mathrm{Mo}$ & $1.76 \pm 0.57$ & $1.9681 \pm 0.53$ & $1.17 \pm 0.13$ & $1.21 \pm 0.15$ \\
\hline $\mathrm{Se}$ & $0.123 \pm 0.015$ & $0.129 \pm 0.016$ & $0.117 \pm 0.032$ & $0.123 \pm 0.031$ \\
\hline
\end{tabular}

Copper $=\mathrm{Cu}$, molybdenum $=\mathrm{Mo}$, manganese $=\mathrm{Mn}$, selenium $=\mathrm{Se}$, cobalt $=\mathrm{Co}$, iron $=\mathrm{Fe}$, zinc $=\mathrm{Zn}$

Note: Different little letters show extremely significant difference $(P<0.01)$. 
Table 2. Mineral content of blood and liver $\mathrm{mg} / \mathrm{kg}$.

\begin{tabular}{|c|c|c|c|c|}
\hline \multirow{2}{*}{ Element } & \multicolumn{2}{|c|}{ Blood } & \multicolumn{2}{c|}{ Liver } \\
\cline { 2 - 5 } & Affected animals & Healthy animals & Affected animals & Healthy animals \\
\hline $\mathrm{Mn}$ & $0.57 \pm 0.17$ & $0.56 \pm 0.19$ & $4.31 \pm 0.37$ & $4.29 \pm 0.39$ \\
\hline $\mathrm{Zn}$ & $7.83 \pm 0.19$ & $7.79 \pm 0.89$ & $71.49 \pm 13.21$ & $71.39 \pm 17.17$ \\
\hline $\mathrm{Co}$ & $0.63 \pm 0.17$ & $0.64 \pm 0.13$ & $7.25 \pm 1.22$ & $7.18 \pm 1.23$ \\
\hline $\mathrm{Cu}$ & $8.57 \pm 0.37 \mathrm{a}$ & $0.97 \pm 0.11 \mathrm{~b}$ & $802.76 \pm 52.77 \mathrm{a}$ & $94.19 \pm 21.17 \mathrm{~b}$ \\
\hline $\mathrm{P}$ & $233.67 \pm 21.79$ & $241.83 \pm 21.77$ & $612.89 \pm 35.71$ & $613.97 \pm 32.94$ \\
\hline $\mathrm{Mo}$ & $0.08 \pm 0.13$ & $0.09 \pm 0.11$ & $3.17 \pm 0.79$ & $3.17 \pm 0.83$ \\
\hline $\mathrm{Se}$ & $0.147 \pm 0.061$ & $0.153 \pm 0.032$ & $1.193 \pm 0.061$ & $1.174 \pm 0.315$ \\
\hline
\end{tabular}

Copper $=\mathrm{Cu}$, molybdenum $=\mathrm{Mo}$, manganese $=\mathrm{Mn}$, selenium $=\mathrm{Se}$, cobalt $=\mathrm{Co}$, iron $=\mathrm{Fe}$, zinc $=\mathrm{Zn}$

Note: Different little letters show extremely significant difference $(P<0.01)$.

\section{Effect of Mo in Feed on $\mathrm{Cu}$ Content in Blood and Liver}

Copper contents in blood and liver were greatly increased, impairing appetite, lassitude and so on symptoms caught up with sheep after the $30 \mathrm{~d}$ of transfer stocking in the pasture of affected pasture from the control pasture. Molybdenum supplementation ameliorated these disease symptoms, which eventually disappeared by the end of the trial. The therapeutic effects of different supplementary doses were different (Fig. 1). From Fig. 1 we can see that the copper content in blood and liver had no significant change of Wumeng semi-fine wool sheep in the drug control group (CK group), and the symptoms of dyspnea, jaundice and hemoglobinuria appeared. Among the three groups added with ammonium molybdate, $300 \mathrm{mg} / \mathrm{kg}$ had the fastest effect. After 20 days of feeding, the copper content in blood decreased by more than $50 \%$. After 40 days of continuous feeding, the copper content in

Table 3. Physiological parameters in blood.

\begin{tabular}{|c|c|c|}
\hline Blood parameters & Affected animals & Healthy animals \\
\hline $\mathrm{Hb}(\mathrm{g} / \mathrm{L})$ & $82.67 \pm 12.13 \mathrm{a}$ & $123.37 \pm 13.58 \mathrm{~b}$ \\
\hline $\mathrm{RBC}\left(10^{12} / \mathrm{L}\right)$ & $6.75 \pm 2.87 \mathrm{a}$ & $11.69 \pm 1.35 \mathrm{~b}$ \\
\hline $\mathrm{PCV}(\%)$ & $22.57 \pm 2.35 \mathrm{a}$ & $36.87 \pm 5.36 \mathrm{~b}$ \\
\hline $\mathrm{MCV}($ fl. $)$ & $2.57 \pm 0.37 \mathrm{a}$ & $3.19 \pm 0.43 \mathrm{a}$ \\
\hline $\mathrm{MCH}($ pg. $)$ & $12.35 \pm 2.61$ & $10.65 \pm 3.17$ \\
\hline $\mathrm{MCHC}(\%)$ & $3.16 \pm 0.37$ & $3.33 \pm 0.37$ \\
\hline $\mathrm{WBC}\left(10^{\%} / \mathrm{L}\right)$ & $10.77 \pm 1.72$ & $9.25 \pm 2.37$ \\
\hline
\end{tabular}

Hemoglobin $=\mathrm{Hb}$, red blood cell count $=\mathrm{RBC}$,

hematocrit $=\mathrm{PCV}$, mean corpuscular volume $=\mathrm{MCV}$, mean corpuscular hemoglobin $=\mathrm{MCH}$, mean corpuscular hemoglobin concentration $=\mathrm{MCHC}$, white blood cell count $=\mathrm{WBC}$

Note: Different little letters show extremely significant difference $(P<0.01)$. blood was $1.28 \mathrm{mg} / \mathrm{kg}$ and was restored to the normal range of $0.7-1.3 \mathrm{mg} / \mathrm{kg}$. The 100 and $200 \mathrm{mg} / \mathrm{kg}$ groups added with molybdenum needed around 40 days to reduce the copper content in blood by $50 \%$, and the time required to reduce the copper content in blood to the normal range was longer. It can be seen that supplementing ammonium molybdate twice every 10 days and $300 \mathrm{mg} / \mathrm{kg}$ each time is the best way to solve copper poisoning in Wumeng semi-fine wool sheep in this area.

\section{Effect of Mo in Feed on Blood Physiological and Biochemical Indicators}

At the end of the ammonium molybdate supplementation experiment, $\mathrm{Hb}, \mathrm{RBC}$ and $\mathrm{MCH}$ in blood in the ammonium molybdate supplementation groups were significantly higher than those in the CK group $(P<0.01)$, and there was no significant difference among $\mathrm{PCV}, \mathrm{MCHC}$ and $\mathrm{WBC}$ in the four groups $(P>0.01)$ (Table 5). The activity of SOD, CAT, and

Table 4. Biochemical parameters in blood.

\begin{tabular}{|c|c|c|}
\hline Biochemical parameters & Affected animals & Healthy animals \\
\hline SOD $(\mathrm{IU} / \mathrm{mL})$ & $32.87 \pm 3.91 \mathrm{a}$ & $71.67 \pm 7.53 \mathrm{~b}$ \\
\hline CAT $(\mathrm{IU} / \mathrm{mL})$ & $0.75 \pm 0.27 \mathrm{a}$ & $1.23 \pm 0.31 \mathrm{~b}$ \\
\hline GSH-Px $(\mathrm{IU} / \mathrm{mL})$ & $13.23 \pm 6.31 \mathrm{a}$ & $33.76 \pm 3.73 \mathrm{~b}$ \\
\hline $\mathrm{Cp}(\mathrm{mg} / \mathrm{dL})$ & $8.76 \pm 1.33 \mathrm{a}$ & $4.49 \pm 1.53 \mathrm{~b}$ \\
\hline $\mathrm{MDA}(\mathrm{nmol} / \mathrm{mL})$ & $36.47 \pm 3.35 \mathrm{a}$ & $27.18 \pm 5.34 \mathrm{~b}$ \\
\hline CPK $(\mathrm{IU} / \mathrm{mL})$ & $101.76 \pm 21.67 \mathrm{a}$ & $35.77 \pm 3.75 \mathrm{~b}$ \\
\hline GOT $(\mathrm{IU} / \mathrm{mL})$ & $47.87 \pm 3.39 \mathrm{a}$ & $16.48 \pm 3.87 \mathrm{~b}$ \\
\hline
\end{tabular}

Glutathione peroxidase $=\mathrm{GSH}-\mathrm{Px}$, glutamic oxaloacetic transaminase $=\mathrm{GOT}$, catalase $=\mathrm{CAT}$,

creatine phosphokinase $=\mathrm{CPK}$, superoxide dismutase $=\mathrm{SOD}$, malondialdehyde $=\mathrm{MDA}$, ceruloplasmin $=\mathrm{Cp}$

Note: Different little letters show extremely significant difference $(P<0.01)$. 

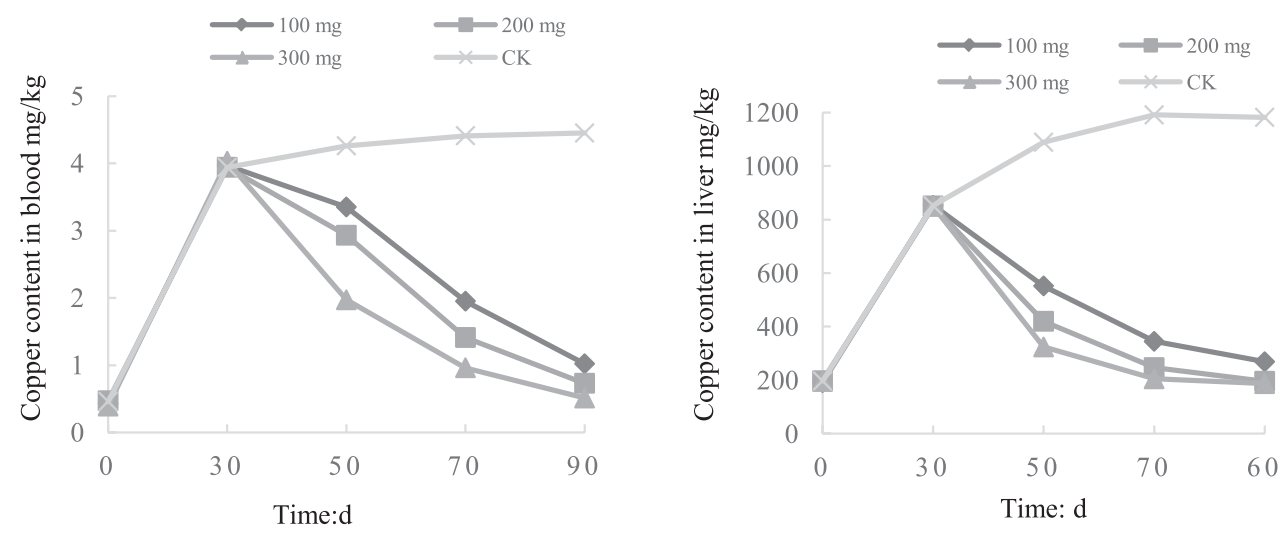

Fig. 1. Effect of ammonium molybdate on copper content in blood and liver.

GSH-Px in blood in ammonium molybdate supplementation groups were significantly higher than those in the CK group $(P<0.01)$, while the activity of CPK, GOT, CP and MDA in blood in ammonium molybdate supplementation groups were significantly lower than those in the $\mathrm{CK}$ group $(P<0.01)$ (Table 6).

\section{Discussion}

Mineral elements, as inorganic nutrients are a major category of animal nutrients, play an important role in the animals' growth and development, function maintenance, quality of product and immune function and so on [15-17], but when the content exceeds the requirement, it will show certain toxicity $[18,19]$. The soil has to provide the mineral nutrients for the plants, and the plants in turn must make the nutrient elements absorbed from the soil available to the animal. The evidence of interdependence among the soil, plant and animal should be the basis for the provision of an adequate source of food for man [20]. Therefore, the accumulation of heavy metals in the environment not only directly influence animal health, but also affect human health through the food chain [21, 22]. In this study, copper content in blood and liver in the sheep that grazed on the copper-polluted meadow was significantly higher than that in the control pasture. This indicated that excessive copper in the environment had an effect on copper in the sheep.

The red blood cell count and hemoglobin content decreasing have the characteristics of anemia [23]. The red blood cell count and hemoglobin content of sheep grazing on copper-contaminated grassland were significantly lower than those in control group $(P<$ 0.01 , which was consistent with anemia observed in Wumeng sheep.

Aerobic organisms often produce a large number of reactive oxygen species such as superoxide anion radical $\left(\mathrm{O}_{2}^{-}\right)$, hydroxyl radical $(-\mathrm{OH})$, and hydrogen peroxide $\left(\mathrm{H}_{2} \mathrm{O}_{2}\right)$ in the oxidation reduction cycle. If too many free radicals cannot be removed in time, they will attack various biological macromolecules, causing a series of oxidative damage such as DNA damage, enzyme inactivation, lipid peroxidation and so on, and then causing various physiological pathological changes of organisms [24-26]. In the long-term evolution process, organisms have formed a complete protective antioxidant system to remove excess free radicals in the body [27]. The system includes nonenzymatic antioxidants and enzymatic antioxidants. Non-enzymatic antioxidants are mainly vitamins E, vitamin $\mathrm{C}$, glutathione, nitric oxide, $\beta$-carotene, etc. Enzyme antioxidants include superoxide dismutase, catalase and glutathione peroxidase [28, 29]. Superoxide dismutase plays the first role in scavenging reactive

Table 5. Physiological indexes in blood after adding ammonium molybdate.

\begin{tabular}{|c|c|c|c|c|c|c|c|}
\hline $\begin{array}{c}\text { Levels of ammonium } \\
\text { molybdate }(\mathrm{mg} / \mathrm{kg})\end{array}$ & $\begin{array}{c}\mathrm{Hb} \\
(\mathrm{g} / \mathrm{L})\end{array}$ & $\begin{array}{c}\text { RBC } \\
\left(10^{12} / \mathrm{L}\right)\end{array}$ & $\begin{array}{c}\text { PCV } \\
(\%)\end{array}$ & $\begin{array}{c}\text { MCV } \\
(\mathrm{fl})\end{array}$ & $\begin{array}{c}\text { MCH } \\
(\mathrm{pg} .)\end{array}$ & $\begin{array}{c}\text { MCHC } \\
(\%)\end{array}$ & $\begin{array}{c}\text { WBC } \\
\left(10^{9} / \mathrm{L}\right)\end{array}$ \\
\hline 0 & $80.41 \pm 6.17 \mathrm{a}$ & $6.20 \pm 1.14 \mathrm{a}$ & $23.23 \pm 2.09 \mathrm{a}$ & $2.53 \pm 0.59$ & $12.19 \pm 1.56$ & $3.03 \pm 0.59$ & $10.77 \pm 1.73$ \\
\hline 100 & $106.06 \pm 15.44 \mathrm{~b}$ & $10.54 \pm 1.27 \mathrm{~b}$ & $34.31 \pm 1.69 \mathrm{~b}$ & $2.81 \pm 0.52$ & $10.77 \pm 1.21$ & $2.91 \pm 0.52$ & $10.80 \pm 0.92$ \\
\hline 200 & $118.23 \pm 15.31 \mathrm{~b}$ & $10.93 \pm 0.85 \mathrm{~b}$ & $34.51 \pm 1.88 \mathrm{~b}$ & $3.01 \pm 0.43$ & $11.57 \pm 1.21$ & $3.07 \pm 0.43$ & $10.24 \pm 1.98$ \\
\hline 300 & $119.67 \pm 10.04 \mathrm{~b}$ & $11.67 \pm 1.48 \mathrm{~b}$ & $35.46 \pm 1.67 \mathrm{~b}$ & $3.15 \pm 0.49$ & $10.62 \pm 3.19$ & $3.15 \pm 0.49$ & $9.64 \pm 2.54$ \\
\hline
\end{tabular}

Hemoglobin $=\mathrm{Hb}$, red blood cell count $=\mathrm{RBC}$, hematocrit $=\mathrm{PCV}$, mean corpuscular volume $=\mathrm{MCV}$, mean corpuscular hemoglobin $=\mathrm{MCH}$, mean corpuscular hemoglobin concentration $=\mathrm{MCHC}$, white blood cell count $=\mathrm{WBC}$ Note: Different little letters show significant difference $(P<0.01)$. 
Table 6. Biochemical indexes in blood after adding ammonium molybdate.

\begin{tabular}{|c|c|c|c|c|c|c|c|}
\hline $\begin{array}{c}\text { Levels of ammonium } \\
\text { molybdate }(\mathrm{mg} / \mathrm{kg})\end{array}$ & $\begin{array}{c}\text { SOD } \\
(\mathrm{IU} / \mathrm{mL})\end{array}$ & $\begin{array}{c}\text { CAT } \\
(\mathrm{IU} / \mathrm{mL})\end{array}$ & $\begin{array}{c}\text { GSH-Px } \\
(\mathrm{IU} / \mathrm{mL})\end{array}$ & $\begin{array}{c}\text { CP } \\
(\mathrm{mg} / \mathrm{dL})\end{array}$ & $\begin{array}{c}\text { MDA } \\
(\mathrm{nmol} / \mathrm{mL})\end{array}$ & $\begin{array}{c}\text { CPK } \\
(\mathrm{IU} / \mathrm{mL})\end{array}$ & $\begin{array}{c}\text { GOT } \\
(\mathrm{IU} / \mathrm{mL})\end{array}$ \\
\hline 0 & $31.05 \pm 2.86 \mathrm{a}$ & $0.65 \pm 0.21 \mathrm{a}$ & $12.63 \pm 3.06 \mathrm{a}$ & $8.64 \pm 1.32 \mathrm{a}$ & $33.38 \pm 3.22 \mathrm{a}$ & $102.40 \pm 8.32 \mathrm{a}$ & $47.75 \pm 4.26 \mathrm{a}$ \\
\hline 100 & $62.78 \pm 6.87 \mathrm{~b}$ & $1.04 \pm 0.15 \mathrm{~b}$ & $30.37 \pm 2.26 \mathrm{~b}$ & $5.01 \pm 0.94 \mathrm{~b}$ & $27.31 \pm 2.08 \mathrm{~b}$ & $36.22 \pm 4.44 \mathrm{~b}$ & $19.34 \pm 2.06 \mathrm{~b}$ \\
\hline 200 & $67.48 \pm 4.00 \mathrm{~b}$ & $1.15 \pm 0.27 \mathrm{~b}$ & $32.95 \pm 3.66 \mathrm{~b}$ & $4.81 \pm 1.09 \mathrm{~b}$ & $28.28 \pm 3.28 \mathrm{~b}$ & $33.98 \pm 5.87 \mathrm{~b}$ & $19.14 \pm 2.86 \mathrm{~b}$ \\
\hline 300 & $71.21 \pm 4.20 \mathrm{~b}$ & $1.23 \pm 0.18 \mathrm{~b}$ & $33.53 \pm 3.69 \mathrm{~b}$ & $4.93 \pm 1.06 \mathrm{~b}$ & $27.22 \pm 2.91 \mathrm{~b}$ & $34.81 \pm 7.19 \mathrm{~b}$ & $17.74 \pm 1.36 \mathrm{~b}$ \\
\hline
\end{tabular}

glutathione peroxidase $=$ GSH-Px, glutamic oxaloacetic transaminase $=$ GOT, catalase $=\mathrm{CAT}$, creatine phosphokinase $=\mathrm{CPK}$, superoxide dismutase $=\mathrm{SOD}$, malondialdehyde $=\mathrm{MDA}$, ceruloplasmin $=\mathrm{Cp}$

Note: Different little letters show significant difference $(P<0.01)$.

oxygen species (ROS). It rapidly disproportionates superoxide anion radicals into hydrogen peroxide and molecular oxygen. Hydrogen peroxide is converted into water and molecular oxygen under the action of catalase and glutathione peroxidase. Therefore, superoxide dismutase, catalase and glutathione peroxidase can scavenge oxygen-free radicals and protect cells from oxidative damage. The studies on the effects of high copper and copper poisoning on animal blood indicators have found that high copper can increase superoxide dismutase, ceruloplasmin and glutathione peroxidase activities in liver and blood, but can inhibit superoxide dismutase and glutathione peroxidase activity after copper poisoning $[30,31]$. There were significant differences in the blood parameters in copper-poisoning sheep illustrated by elevated levels of serum aspartate aminotransferase (AST), creatine phosphokinase, and gamma-glutamyltransferase (GGT) activities [32]. In this experiment, the blood glutathione peroxidase activity of sheep in the affected group was lower than that in the control group, which indicated that a copper-contaminated environment has an effect on the antioxidant system of sheep. Besides, the activities of malondialdehyde and glutamic oxaloacetic transaminase in blood in the affected group were significantly higher than those in the control group, which was the result of copper poisoning promoting the production of lipid peroxides and liver injury.

After adding ammonium molybdate, copper in blood and liver decreased, hemoglobin and red blood cell count content and glutathione peroxidase activity increased, and malondialdehyde and glutamic oxaloacetic transaminase activity decreased. This is consistent with the result of previous studies that molybdenum blocks copper absorption, highlighting the antagonism between molybdenum and copper, and forms thiomolybdate in the gastrointestinal tract [3335], in addition to the formation of $\mathrm{Cu}$-thiomolybdate complexes and Cu-Mo-S-protein compounds [36, 37]. Cu-thiomolybdate complexes are insoluble and excreted directly from the intestinal tract, which blocks the absorption of copper, resulting in decreased copper levels. Cu-Mo-S-protein compounds are more stable in the blood and copper is not easily utilized by tissue. In the liver, the thiomolybdate anions can directly peel copper away from the metallothionein protein, and the peeled copper enters the blood and bile by way of other small metalloproteins that then transfer the copper to other proteins, and so on, which results in the gradual decrease of copper stores in the liver of sheep under grazing conditions and eventual depletion. In the "digestive tract effect-systematical effect" proposed by Mason Smith when describing the interactions among three species, it was also mentioned that molybdate in feed can react with sulfur compounds to produce thiomolybdate in the rumen of ruminants, which then reacts with copper to produce insoluble $\mathrm{Cu}$-thiomolybdate complexes so as to reduce the absorption of copper. Secondly, protein-Cu-Mo compounds are formed, but cannot be utilized physiologically by combining some form of absorbed molybdenum with plasma proteins and copper in the plasma so as to reduce the absorption of copper. Therefore, molybdenum supplementation can reduce copper absorption of Wumeng semi-fine wool sheep and prevent chronic copper poisoning caused by excessive long-term copper intake. However, excessive molybdenum supplementation will cause an imbalance in the $\mathrm{Mo}: \mathrm{Cu}$ ratio, which will also have a serious impact on animal health [38-40]. Moreover, excessive molybdenum supplementation of the diet is a known cause of secondary copper deficiency-related diseases and an inappropriate proportion of molybdenum-tocopper in ruminant feed may also cause symptoms of molybdenum poisoning, such as anorexia, growth stagnation, weight loss, anemia, depilation, dermatitis, loss of hair color, and spontaneous fracture. The suitable $\mathrm{Mo}: \mathrm{Cu}$ ratio in feed is 6-10:1. An $\mathrm{Mo:Cu}$ ratio of less than 2:1 will cause an increase in molybdenum absorption and enhance the reabsorption of metabolic molybdenum by the renal tubules [41, 42]. Therefore, in order to prevent the adverse effects caused by the maladjustment of the $\mathrm{Mo}: \mathrm{Cu}$ ratio due to excessive supplementation of molybdenum in feed, it is necessary to monitor copper intake and to supplement molybdenum according to the appropriate proportion of copper and molybdenum. 


\section{Conclusions}

Copper-contaminated grassland increased the content of copper in blood and liver of grazing Wumeng semi-fine wool sheep, which had a negative impact on blood physiological and biochemical indicators. Supplementation of ammonium molybdate in diet ( 2 every 10 days, $300 \mathrm{mg} / \mathrm{kg}$ each time) can restore abnormal blood parameters to normal. Therefore, utilize the antagonism of molybdenum and copper in the diet to achieve the goal of harmless utilization of the copper-polluted meadow. We should pay attention to the rational formulation of feed for the non-infected sheep to avoid diseases caused by excessive nutrients or lack of them.

\section{Acknowledgments}

This work was supported as a project of the National Key Research and Development Program of China in the $13^{\text {th }}$ Five-Year Plan (2016YFC0502601), the National Natural Science Foundation of China (41671041), and the Doctoral Program Foundation of Southwest University of Science and Technology of China (17zx7146).

\section{Competing Financial Interests}

The authors declare they have no present or potential competing financial interests.

\section{References}

1. LI L.J., SHEN X.Y. Development progress and breeding status of the Wumeng semi-fine wool sheep. Guizhou Agric Sci, 38 (11), 182, 2010.

2. LIAO J.J., SHEN X.Y., HUO B., XIONG K.N. Effect of nitrogenous fertilizer on the antioxidant systems of grassland species in the Karst mountains. Acta Prataculturae Sin 27 (1), 169, 2018.

3. HUO B., WU T., MIN X.Y., SHEN X.Y. Effect of molybdenum fertilizer treatment to copper pollution meadow on copper metabolism in Wumeng semi-fine wool sheep. J Domestic Anim Ecol, 40 (3), 56, 2019.

4. SONG D.R., ZHOU D.R., PENG H. Analysis on some characters of Guizhou semi-fine wool sheep before and after breeding. Acta Agriculturae Boreali-Occidentalis Sinica, 23 (11), 1, 2014 [In Chinese].

5. CHI Y.K., XIONG K.N., CHEN H., MIN X.Y., XIAO H., LIAO J.J., SHEN X.Y. Effect of Grazing to Copper Pollution Meadow on Copper Metabolism in Wumeng Semi-fine Wool Sheep. Pol J Environ Stud, 28 (3), 1, 2019.

6. WANG X.L., CHEN Z.F., WEI Z.D., FAN L.D., ZHANG X.S., PEI J.C. Heavy metal pollution and potential ecological risk assessment in agricultural soils located in the peri-urban area of Kaifeng City. Environ Chem, 37 (3), 513, 2018.

7. ZHANG P., QIN C., HONG X., KANG G., QIN M., YANG D., PANG B., LI Y., HE J., DICK R.P. Risk assessment and source analysis of soil heavy metal pollution from lower reaches of Yellow River irrigation in China. Sci Total Environ, 633, 1136, 2018.

8. BAI J.H., CUI B.S., CHEN B., ZHANG K.J., DENG W., GAO H.F., XIAO R. Spatial distribution and ecological risk assessment of heavy metals in surface sediments from a typical plateau lake wetland, China. Ecol Model, 222, 301, 2011.

9. GUAN H.F. Diagnosis and control measures of sheep copper poisoning. Modern Animal Husbandry Science and Technology, 7, 128, 2013 [In Chinese].

10. YAO L., PENG T., LI J. Effect of liver biopsy on blood routine and liver function in peripartum goats. Prog Vet Med, 38 (6), 128, 2017.

11. SHEN X.Y., ZHANG R.D. Studies on "stiffness of extremities disease" in the yak (Bos mutus). J. Wildlife Dis, 8, 542, 2012.

12. SHEN X.Y., ZHANG J.H., ZHANG R.D. Studies on phosphorus metabolic disorder in Guizhou semi-fine wool sheep. PLos One, 9, e89472, 2014.

13. YANG Z.J., ZHANG C., WANG H.W. Effect of copper and zinc on the level of molybdenum in liver and kidney of sheep with experimental molybdenum poisoning. Chinese J. Vet Sci, 31 (6), 895, 2011.

14. WANG W.X., LI X.T., GUO L.M. Occurrence, diagnosis and treatment of chronic copper poisoning in sheep. Modern Animal Husbandry Science \& Technology, 10, 140, 2015.

15. FANG R.J., XIANG Z.F., YANG Y.S., CAO M.H. Mineral element ideal pattern - from theory to practice. Chinese J. Anim N, 25 (5), 891, 2013.

16. BAI M.M., LIU H.N., ZHANG X.F., XU K., XI Q.Y., DENG J.P., YIN Y.L. Effects of addition of coated cysteamine in reducing mineral elements diet on growth performance, carcass quality, mineral elements deposition and excretion of finishing pigs. Chinese J. Anim N, 29 (12), 4447, 2017.

17. ARNESANO F., BANCI L., IVANO B.A. Ortholog search of proteins involved in copper delivery to cytochrome $\mathrm{C}$ oxidase and functional analysis of paralogs and gene neighbors by genomic context. J. Proteome Res, 4 (1), 63, 2005.

18. HEFNAWY A.E., EI-KHAIAT H.M. The importance of copper and the effects of its deficiency and toxicity in animal health. Int J. Livest Res, 5 (12), 1, 2015.

19. JIANG W.D., LIU Y., JIANG J., HU K., LI S.H., FENG L., ZHOU X.Q. In vitro interceptive and reparative effects of myo-inositol against copper-induced oxidative damage and antioxidant system disturbance in primary cultured fish enterocytes. Aquat toxicol, 132 (2), 100, 2013.

20. PRASAD R. Micro mineral nutrient deficiencies in humans, animals and plants and their amelioration. P. Natl A. Sci India, 82 (2), 225, 2012.

21. SINGH A.L., SINGH P.K., KUMAR A., SINGH M.P. Sequestration of metals from coal using bacteria: environmental implications on clean coal energy. Energ Source Part A, 37 (13), 1432, 2015.

22. MITKOVA T., PRENTOVIC' T., MARKOSKI M. Phytoremediation of soils contaminated with heavy metals in the vicinity of the smelter for lead and zinc in Veles. Agric Conspec Sci, 80 (1), 53, 2016.

23. WEN R.Y., LUO X., ZHENG Y.Y., ZHOU L., LIAO H.F., LIU Q. Rhubarb peony decoction ameliorate DSS-induced uicerative colitis and its associated anemia in mice. Chinese archives of traditional chinese medicine, 34 (12), 184, 2016 [In Chinese]. 
24. JIN L.H., BAHN J.H., EUM W.S., KWON H.Y., JANG S.H., HAN K.H., KANG T.C., WON M.H., KANG J.H., CHO S.W., PARK J., CHOI S.Y. Transduction of human catalase mediated by an HIV-1 TAT protein basic domain and arginine-rich peptides into mammalian cells. Free Radical Biol Med, 31 (11), 1509, 2001.

25. SULIBURSKA J., BOGDANSKI P., SZULINSKA M., STEPIEN M., PUPEK-MUSIALIK D., JABLECKA A. Effects of green tea supplementation on elements, total antioxidants, lipids, and glucose values in the serum of obese patients. Biol Trace Elem Res, 149 (3), 315, 2012.

26. BASAKI M., NAZIFI S., SHAMSAEI H.A. Zinc, copper, iron, and chromium concentrations in young patients with type 2 diabetes mellitus. Biol Trace Elem Res, 148 (2), 161, 2012.

27. SILVA E.P.J., BORGES L.S., MENDES-DA-SILVA C., HIRABARA S.M., LAMBERTUCCI R.H. 1 -Arginine supplementation improves rats' antioxidant system and exercise performance. Free Radical Res, 51 (3), 1, 2017.

28. SHEN X.Y. Effect of nitrogenous fertilizer treatment on mineral metabolism in grazing yaks. Agr Sci China, 8 (3), 361, 2009.

29. GUAN T., SONG J., WANG Y., GUO L., ZHAO Y., GAO Y., LIN L., WANG Y., WEI J. Expression and characterization of recombinant bifunctional enzymes with glutathione peroxidase and superoxide dismutase activities. Free Radical Biol Med, 110, 188, 2017.

30. CUI H.M., CHEN H.T. Effect of copper toxicity on some blood parameters in ducklings. Chinese J. Vet, 25 (3), 31, 2005.

31. JIA X.Y., CHEN Z.W. The effects of $\mathrm{Cu} \sim(2+), \mathrm{Cd}(2+)$ on superoxide activities in carassius auratus. Acta Hydrobiol Sinica, 27 (3), 323, 2003.

32. SALARAMOLI J., YAZDANI S., ALIESFAHANI T., RANJBAR N. An evaluation of some oxidative and enzymatic biomarkers in different stages of naturally occurring copper poisoning in sheep. Iran J. Vet Med, 9 (1), 13, 2015.

33. SUTTLE N.F. Responsiveness of prehaemolytic copper poisoning in sheep from a specific pathogen-free environment to a relatively high dose of tetrathiomolybdate Vet Rec, 171 (10), 246, 2012.

34. MORGAN P., GRACE N., LILLEY D. Using sodium molybdate to treat chronic copper toxicity in dairy cows: A practical approach. New Zeal Vet J, 62 (3), 167, 2014.

35. JOHNSTON H., BEASLEY L., MACPHERSON N. Copper toxicity in a New Zealand dairy herd. Irish Vet J, 67 (1), 20, 2014.

36. WOOLLIAMS J.A., SUTTLE N.F., WIENER G., FIELD A.C. The long-term accumulation and depletion of copper in the liver of different breeds of sheep fed diets of differing copper content. J. Agr Sci, 100 (2), 441, 1983.

37. SIVERTSEN T., LØVBERG K.E. Seasonal and individual variation in hepatic copper concentrations in a flock of Norwegian Dala sheep. Small Ruminant Res, 116 (1), 57, 2014.

38. ZHANG H., ZHAO J., LIN C. Observation of the immunoeffects on the mice immunized by different isoforms of metallothionein. J. Datong Mad College, 3, 1, 2000.

39. JIN Y.H., ZHU X.P., JIA Z.H., ZHANG W., LI H.G. Influence of copper and molybdenum supplementation on nutrient digestion and metabolism in Liaoning cashmere goats. J. China Agric University, 15 (4), 76, 2010.

40. MINERVINO A.H., BARRÊTO R.A.B., FERREIRA R.N., RODRIGUES F.A., HEADLEY S.A., MORI C.S., ORTOLANI E.L. Clinical observations of cattle and buffalos with experimentally induced chronic copper poisoning. Res Vet Sci, 87 (3), 473, 2009.

41. APARICIOCECILIO A., BOUDA J., SALGADOHERNÁNDEZ E.G., NÚÑEZOCHOA L., CASTILLOMATA D.A., GUTIÉRREZCHÁVEZ A. Effect of 2-methyl-2-phenoxy propionic acid on serum lipid profile and ovarian activity in dairy cows. Czech J. Anim Sci, 12, 550, 2012.

42. YANG Z.J., ZHANG C., WANG H.W., LIU F.J., RAN L.W., WANG J.C. Effect of copper and zinc on the level of molybdenum in liver and kidney of sheep with experimental molybdenum poisoning. Chinese J. Vet Sci, 31 (6), 895, 2011. 